\title{
Evaluation of Adding Desmopressin to Alpha Blockers in Treatment of Nocturia in Cases of Benign Prostatic Hyperplasia: A Prospective Randomized Clinical Study Khaled Mohammed Abdelwahab, AbdEllatif Mohammed AbdEllatif, Ibrahim Ali Ibrahim Jaedah*, Maged Mohammed Ali \\ Department of Urology, Faculty of Medicine, Zagazig University, Egypt \\ *Corresponding author: Ibrahim A. Jaedah, Email: IbrahimJaedah@gmail.com
}

\begin{abstract}
Background: Nocturia is one of the most bothersome symptom of lower urinary tract symptoms in males with Benign Prostatic Hyperplasia (BPH). Alpha blockers has good effect in relieving bladder outlet obstruction.

Objective: The aim of the present study was to provide best available medical treatment for nocturia in patients of BPH. Patients and methods: This prospective study was carried out on 44 male patients complaining of lower urinary tract symptoms (LUTS) of BPH with nocturia, were enrolled in this prospective randomized study for 12 weeks. They were divided randomly into 2 groups, each group included 22 patients. Group A: the patient received oral desmopressin added to tamsulosin once daily. Group B, the patient received oral tamsulosin daily.

Results: The mean serum Na of patients at group A was 142.35. No significant difference regarding in-between groups before treatment but at after 12 week of treatment; group A was (mean of $\mathrm{Na}=137.68 \pm 2.033$ ) significantly lower than group B and significantly decreased from before to after treatment. There was no significant difference between groups in both nocturnal void and nocturnal volume before treatment and after treatment as group A was significantly lower and both groups significantly changed and improved from before to after treatment. No significant difference was found at before treatment regarding total International Prostate Symptom Score (IPSS) but group A was significantly lower regarding total IPSS after treatment and both groups significantly decreased after treatment $(6.36 \pm 2.59$ in group A and $10.55 \pm 4.13$ in group B).
\end{abstract}

Conclusion: Addition of desmopressin to $\alpha$-blockers is an active therapy for men with BPH and suffering nocturia and is preferred than $\alpha$-blockers therapy alone.

Keywords: Alpha Blockers, BPH, Desmopressin, Nocturia.

\section{INTRODUCTION}

Polyuria is defined as a 24-h urine volume of $>40$ $\mathrm{mL} / \mathrm{kg}$ body weight, with nocturnal polyuria (NP) defined as a proportion of the 24-h urine voided at night being $>20-33 \%$. NP is the most likely cause of persistent nocturia in most patients who are treated for benign prostatic hyperplasia (BPH) ${ }^{(1)}$. In men with benign prostatic hyperplasia (BPH), nocturia is considered to be one of the most bothersome lower urinary tract symptoms (LUTS), with a positive correlation between degree of severity and increased bother ${ }^{(2)}$.

Vasopressin also plays a minor role in increasing systemic vascular resistance and increasing urea reabsorption in the medullary collecting tubule. It is the most frequently tested medication for the specific treatment of nocturia, but has traditionally been used to treat central diabetes insipidus, bleeding disorders such as Von Willebrand disease, and primary nocturnal enuresis ${ }^{(3)}$. Desmopressin, a synthetic analogue of arginine vasopressin, has antidiuretic effects and leads to a significant decrease in nocturnal urine output as well as the number of nocturia episodes in nocturnal polyuria ${ }^{(4)}$. The routine addition of oral desmopressin to alpha blocker therapy to improve patients' bother symptoms is questionable ${ }^{(5)}$.

The aim of this study is to provide best available medical treatment for nocturia in patients of BPH by evaluating the outcome (safety and efficacy) of oral desmopressin in treatment of nocturia in patients with BPH.

\section{PATIENTS AND METHODS}

This prospective study was carried out at the Department of Urology, Zagazig University Hospital on 44 male patients complaining of lower urinary tract symptoms (LUTS) of BPH with nocturia, were enrolled in this prospective randomized study for 12 weeks.

Inclusion criteria: Males with BPH and nocturia 2 times or more/night.

Exclusion criteria: Cases with the following conditions were excluded from the study: diabetes insipidus, diabetes mellitus (uncontrolled), polydipsia, congestive heart failure, treatment with diuretics, impaired renal function.

\section{Methods:}

Patients were divided randomly by using computer randomization program (Random-allocation software) into 2 parallel groups; $1^{\text {st }}$ group (Group A) patients took alpha blockers (oral tamsulosin $0.4 \mathrm{mg}$ at bedtime) with desmopressin for 12 weeks. $2^{\text {nd }}$ group (Group B) patients took alpha blockers (oral tamsulosin $0.4 \mathrm{mg}$ at bedtime for 12 weeks) only.

Dose of the drug:

Desmopressin is administered orally at bedtime for 12 weeks usually beginning with $0.1 \mathrm{mg}$. Dose increase or decrease was permitted upon patient 
response in 1-week intervals to a maximum desmopressin dose of $0.4 \mathrm{mg}$ and a minimum dose of $0.05 \mathrm{mg}^{(6)}$.

\section{Assessment of Patients:}

A detailed history of the problem was required for all patients, especially history of LUTS with focus on nocturnal polyuria by using:

○ International Prostate Symptom Score (IPSS):

The IPSS is an 8-item questionnaire, consisting of seven symptom questions and one Quality of life (QOL) question, which is (IPSS question 8): "If you were to spend the rest of your life with your urinary condition the way it is now, how would you feel about that?" with a score of 0 (delighted) to 6 (terrible).

○ Bladder diary \{Frequency voiding chart (FVC): was done for all cases. Patients were asked to complete 3-day FV charts. They were taught how to precisely complete the FV charts by the urologist and were asked not to alter their usual fluid intake and voiding habits during the study.

○ ICIQ-N (International Consultation on Incontinence Modular Questionnaire-Nocturia) is a questionnaire for evaluating the frequency of daytime and night time urination and impact on quality of life (QOL) and outcome of treatment in patient. It is a validated questionnaire for a recall period of 4 weeks with a total of two items. It assesses how much nocturia is a problem with a score of 0 (no problem) to 10 (serious problem).

\section{Laboratory assessment:}

○ Urine analysis; Urinalysis (dipstick or sediment) was included in the primary evaluation of any patient presenting with LUTS to determine conditions such as diabetes mellitus.

○ Serum electrolytes; $(\mathrm{Na}, \mathrm{K})$ : At the time of treatment initiation or dose change, older men with normal values of serum sodium were monitored by $\mathrm{Na}$ measurement at day three and day seven of treatment, and one month later. If serum sodium concentration remained normal, no dose adjustment was intended. Patients were informed about the symptoms of hyponatremia (headache, nausea or insomnia)

o RFT; renal function was assessed by serum creatinine.

\section{Radiological assessment:}

- Abdominal and pelvic ultrasound (US); used to evaluate both kidneys, urinary bladder and prostate with lower cost, lower radiation dose and less side effects.

o Post-void residue; Post-void residual (PVR) urine was assessed by transabdominal US, bladder scan or catheterisation. PVR is not necessarily associated with bladder outlet obstruction (BOO), since high volumes can be a consequence of obstruction and/or detrusor function (detrusor underactivity).

\section{Ethical consent:}

An approval of the study was obtained from Zagazig University academic and ethical committee. Every patient signed an informed written consent for acceptance of the operation. This work has been carried out in accordance with The Code of Ethics of the World Medical Association (Declaration of Helsinki) for studies involving humans.

\section{Statistical analysis:}

Data were recorded using Microsoft Excel software. Data were then imported into Statistical Package for the Social Sciences (SPSS version 20.0) software for analysis. Data were represented by mean \pm standard deviation (SD) and compared by t test. $\mathrm{P}$ value was set at $<0.05$ for significant results and $<0.001$ for high significant result.

\section{RESULTS} table 1 .

Demographic data of the patients are shown in

Table (1): Demographic data of studied groups

\begin{tabular}{|l|c|c|c|}
\hline & $\begin{array}{c}\text { Group A } \\
(\mathbf{N = 2 2}) \\
\text { Mean } \pm \text { SD }\end{array}$ & $\begin{array}{c}\text { Group B } \\
(\mathbf{N = 2 2}) \\
\text { Mean } \pm \text { SD }\end{array}$ & P \\
\hline Age (year) & $59.64 \pm 3.76$ & $61.05 \pm 2.91$ & 0.166 \\
\hline BMI & $27.29 \pm 1.84$ & $27.23 \pm 1.43$ & 0.913 \\
\hline $\begin{array}{l}\text { Duration } \\
\text { (Weeks) }\end{array}$ & $12.05 \pm 2.72$ & $12.00 \pm 2.5$ & 0.954 \\
\hline
\end{tabular}

SD: Standard deviation, $\mathrm{BMI}=$ body mass index

The mean serum $\mathrm{Na}$ of patients at group $\mathrm{A}$ was significantly lower than group B after 4 and 12 weeks. It was also significantly decreased from before to after treatment in group A (Table 2).

Table (2): Comparison of serum sodium (Na) levels before and after treatment ( 12 weeks) between the studied groups

\begin{tabular}{|c|c|c|c|}
\hline & $\begin{array}{c}\text { Group A } \\
\text { Mean } \pm \text { SD }\end{array}$ & $\begin{array}{c}\text { Group B } \\
\text { Mean } \pm \text { SD }\end{array}$ & $\mathbf{P}$ \\
\hline $\begin{array}{l}\text { Na }(\text { meq/l)/ } \\
\text { before }\end{array}$ & $\begin{array}{c}141.85 \pm 2 \\
152\end{array}$ & $\begin{array}{c}142.18 \pm 1.9 \\
1\end{array}$ & 0.557 \\
\hline $\begin{array}{l}\mathrm{Na} / \text { after } 4 \\
\text { weeks }\end{array}$ & $\begin{array}{c}139.86 \pm 2 \\
12\end{array}$ & $\begin{array}{c}141.86 \pm 1.8 \\
8\end{array}$ & $\begin{array}{c}0.002 \\
*\end{array}$ \\
\hline $\begin{array}{l}\mathrm{Na}(\mathrm{meq} / \mathrm{l}) / \\
\text { after } \\
\text { treatment }\end{array}$ & $\begin{array}{c}137.68 \pm 2 \\
033\end{array}$ & $\begin{array}{c}141.32 \pm 2.0 \\
5\end{array}$ & $\begin{array}{c}<0.00 \\
1\end{array}$ \\
\hline $\mathbf{P}$ & 0.003 & 0.098 & \\
\hline
\end{tabular}

SD: Standard deviation

There was no significant difference between groups in both nocturnal void and nocturnal volume before treatment and after treatment group A was significantly lower than group B and both groups 
significantly changed and improved from before to after treatment (Table 3).

Table (3): Comparison of nocturnal voids and volume in bladder diary before and after treatment between studied groups

\begin{tabular}{|l|c|c|c|}
\hline & $\begin{array}{c}\text { Group A } \\
\text { Mean } \pm \text { S } \\
\text { D }\end{array}$ & $\begin{array}{c}\text { Group B } \\
\text { Mean } \pm \text { SD }\end{array}$ & P \\
\hline $\begin{array}{l}\text { Nocturnal } \\
\text { voids/before } \\
\text { treatment }\end{array}$ & $\begin{array}{c}3.64 \pm 0.6 \\
4\end{array}$ & $3.58 \pm 0.65$ & 0.759 \\
\hline $\begin{array}{l}\text { Nocturnal } \\
\text { void after 4 } \\
\text { weeks }\end{array}$ & $\begin{array}{c}2.32 \pm 0.6 \\
4\end{array}$ & $2.86 \pm 0.64$ & 0.008 \\
\hline $\begin{array}{l}\text { Nocturnal } \\
\text { voids/after } \\
\text { treatment }\end{array}$ & $\begin{array}{c}1.23 \pm 0.7 \\
\text { P1 }\end{array}$ & $2.09 \pm 0.75$ & $<0.00$ \\
\hline $\begin{array}{l}\text { Nocturnal } \\
\text { volume/befo } \\
\text { re } \\
\text { treatment }\end{array}$ & $\begin{array}{c}38.86 \pm 12 \\
.9\end{array}$ & $37.73 \pm 11$. & 0.762 \\
\hline $\begin{array}{l}\text { Nocturnal } \\
\text { volume/afte } \\
\text { r 4 weeks }\end{array}$ & $\begin{array}{c}23.41 \pm 9 . \\
17\end{array}$ & $30.91 \pm 8.4$ & 0.007 \\
\hline $\begin{array}{l}\text { Nocturnal } \\
\text { volume/afte } \\
\text { r treatment }\end{array}$ & $14.01 \pm 6$. & $23.18 \pm 8.2$ & $<0.00$ \\
\hline P 2 & 3 & & 1 \\
\hline SD Standard & $<0.01$ & $<0.01$ & \\
\hline
\end{tabular}

SD: Standard deviation

$\mathrm{P} 1=\mathrm{P}$ value of Nocturnal voids/before and after 4 weeks treatment

$\mathrm{P} 2=\mathrm{P}$ value of Nocturnal volume/before and after 12 weeks treatment

Group A was significantly lower than group B as regard total IPSS after 12 weeks of treatment. Total IPSS in each group significantly decreased after 12 weeks of treatment (Table 4).

Table (4): Comparison of total IPSS before and after treatment between the studied groups

\begin{tabular}{|l|c|c|c|}
\hline & $\begin{array}{c}\text { Group A } \\
\text { Mean } \pm \text { SD }\end{array}$ & $\begin{array}{c}\text { Group B } \\
\text { Mean } \pm \text { SD }\end{array}$ & P \\
\hline $\begin{array}{l}\text { Total } \\
\text { IPSS/before } \\
\text { treatment }\end{array}$ & $23.82 \pm 2.4$ & $23.09 \pm 2.6$ & 0.353 \\
\hline $\begin{array}{l}\text { Total } \\
\text { IPSS/after 4 } \\
\text { weeks }\end{array}$ & $14.18 \pm 3.30$ & $15.82 \pm 3.78$ & 0.134 \\
\hline $\begin{array}{l}\text { Total } \\
\text { IPSS/after } \\
\text { 12 weeks of } \\
\text { treatment }\end{array}$ & $6.36 \pm 2.59$ & $10.55 \pm 4.13$ & $<0.001$ \\
\hline P & & & \\
\hline
\end{tabular}

IPSS: International Prostate Symptom Score, SD:

Standard deviation
Group A was significantly lower than group B as regard total IPSS-QOL after 4 and 12 weeks treatment. Total IPSS-QOL in each group significantly decreased from before to after 12 weeks of treatment (Table 5).

Table (5): Comparison of IPSS-QOL before and after treatment between groups

\begin{tabular}{|l|c|c|c|}
\hline & $\begin{array}{c}\text { Group A } \\
\text { Mean } \pm \text { SD }\end{array}$ & $\begin{array}{c}\text { Group B } \\
\text { Mean } \pm \text { SD }\end{array}$ & P \\
\hline $\begin{array}{l}\text { IPSS- } \\
\text { QOL } \\
\text { /before } \\
\text { treatment }\end{array}$ & $4.41 \pm 0.73$ & $4.50 \pm 0.74$ & 0.685 \\
\hline $\begin{array}{l}\text { IPSS- } \\
\text { QOL } \\
\text { /after 4 } \\
\text { weeks of } \\
\text { treatment }\end{array}$ & $2.23 \pm 0.92$ & $3.45 \pm 0.96$ & $<0.001$ \\
\hline $\begin{array}{l}\text { IPSS- } \\
\text { QOL }\end{array}$ & $1.14 \pm 1.08$ & $2.68 \pm 0.94$ & $<0.001$ \\
$\begin{array}{l}\text { /after 12 } \\
\text { weeks of } \\
\text { treatment }\end{array}$ & & & \\
\hline P & & & \\
\hline
\end{tabular}

SD: Standard deviation

Group A was significantly lower than group B as regard ICIQ-N after 4 and 12 weeks treatment. ICIQ-N in each group significantly decreased after 12 weeks of treatment (Table 6).

Table (6): Comparison of ICIQ-N before and after treatment between the studied groups

\begin{tabular}{|l|c|c|c|}
\hline & $\begin{array}{c}\text { Group A } \\
\text { Mean } \pm \text { SD }\end{array}$ & $\begin{array}{c}\text { Group B } \\
\text { Mean } \pm \text { SD }\end{array}$ & P \\
\hline $\begin{array}{l}\text { ICIQ-N } \\
\text { /before } \\
\text { treatment }\end{array}$ & $6.86 \pm 1.20$ & $6.82 \pm 1.22$ & 0.902 \\
\hline $\begin{array}{l}\text { ICIQ- } \\
\text { N/after 4 } \\
\text { weeks of } \\
\text { treatment }\end{array}$ & $3.82 \pm 1.25$ & $4.73 \pm 1.20$ & 0.019 \\
\hline $\begin{array}{l}\text { ICIQ- } \\
\text { N/after 12 } \\
\text { weeks of } \\
\text { treatment }\end{array}$ & $1.77 \pm 0.86$ & $3.0 \pm 1.02$ & $<0.001$ \\
\hline P & & & \\
\hline
\end{tabular}

SD: Standard deviation

\section{DISCUSSION}

Nocturia is defined as the complaint that the individual has to wake at night one or more times to void ${ }^{(7)}$. Most people with $<2$ voids/night have only minimal bother but when $\geq 2$ voids/night then nocturia may impact health-related quality of life, therefore is considered clinically relevant ${ }^{(8)}$. Several urological and non-urological causes of nocturia exist, alone or in combination ${ }^{(9)}$. 
Tamsulosin ( $\alpha$-blocker) had insignificant effect $(p=0.198)$ on the hours of undisturbed sleep (the time from falling asleep to the first awakening to void), with an increase from baseline of 81 versus $60 \mathrm{~min}$ for placebo. Similarly, tamsulosin only $(\mathrm{p}=0.099)$ reduced nocturia by one nocturnal void versus 0.7 by placebo. So, objectively, tamsulosin had no significant effects ${ }^{(\mathbf{1 0})}$. The objective differences are disappointing due to the fact that nocturnal polyuria is a principal cause of nocturia in up to $70 \%$ of cases ${ }^{(11)}$.

Desmopressin has level 1 evidence and grade A recommendation for the treatment of nocturia due to NP ${ }^{(12)}$. Desmopressin acetate nasal spray has been approved by the USA Food and Drug Administration (FDA) for the treatment of nocturia due to NP in adults (13).

This prospective study was carried out on 44 male patients complaining of LUTs of BPH with nocturia enrolled for 12 weeks, according to inclusion and exclusion criteria mentioned before. They were divided randomly into 2 groups: group (A) included 22 patients who received oral desmopressin added to tamsulosin once daily and group (B) included 22 who received oral tamsulosin daily.

In our study, the mean age, BMI, and duration were not significantly different between groups. These results are in agreement with Mohammed and AlHakeem ${ }^{(14)}$ who included a total of 51 patients and assigned them into two groups, those who remained on an $\alpha$-blocker $(n=22)$, and those who received oral desmopressin $0.2 \mathrm{mg}$ add-on therapy with an $\alpha$-blocker $(\mathrm{n}=29)$. The mean age of the patients on $\alpha$-blockers alone was $(63.95 \pm 10.15)$ years compared to $(62.43 \pm 10.72)$ years for those patients using desmopressin add-on with no significant difference (Pvalue $=0.607$ ).

In our study, the mean serum $\mathrm{Na}$ of patients at group A was 142.35. No significant difference as regard before treatment but at after 4 week 12 week of treatment; group A was significantly lower and significantly decreased from before to after treatment. These results agree with Chen $\boldsymbol{e t} \boldsymbol{a l} .{ }^{(15)}$ who assessed the serum sodium level at 1,4 , and 12 weeks after initiation of desmopressin therapy. The mean (SD) decrease in the serum sodium levels was 3.89 (1.22) $\mathrm{mmol} / \mathrm{L}(\mathrm{P}<0.001)$ in the non-NP group and $4.69(3.5)$ $\mathrm{mmol} / \mathrm{L}(\mathrm{P}<0.001)$ in the NP group. Also, in study involving in $>250000$ patients, Delfanian and Zawada (16) reported certain potential risks for occurrence of hyponatremia after desmopressin administration. These included surgery stress, hepatic disease, increased desmopressin dose, and excessive fluid intake. They concluded that hyponatremia may be prevented by close monitoring of serum electrolytes and avoidance of low sodium solutions.

Based on the degree of bother, the number of night voids that defines clinically significant nocturia is 2 voids/night ${ }^{(\mathbf{1 7})}$. Also, Oelke et al. ${ }^{(\mathbf{8})}$ reported that only $5 \%$ of men presented with nocturia as a single symptom, whereas nocturia concomitantly appeared with other storage and/or voiding LUTS in $20.5 \%$ of men.

In our study, there was significant difference between groups in both nocturnal void and nocturnal volume after treatment as group A was significantly lower and both groups significantly changed and improved from before to after treatment. These results agree with Koca $\boldsymbol{e t}$ al. ${ }^{(\mathbf{1 8})}$ who evaluated desmopressin alone, which significantly decreased the number of nocturnal voids from a baseline mean of 7.0 to 5.7 episodes for 3 days at the 24-week visit.

In our study, there was no significant difference at before treatment as regard total IPSS but group A was significantly lower as regard total IPSS after 12 weeks treatment and both groups significantly decreased from before to after 12 weeks treatment but more in Group A. These results agree with Taha et $\boldsymbol{a l} \mathbf{l}^{(\mathbf{1})}$ who evaluated the combined tamsulosin and desmopressin treatment, which was more effective in treating nocturia but the change in IPSS was more significant in the a-blocker-only group.

In our study, there was no significant difference as regard mean of IPSS-QOL before treatment but in group A it was significantly decreased after 4 and 12 weeks of treatment and in both groups it significantly decreased from before to after 12 weeks of treatment but more in Group A. Weiss et al. ${ }^{(19)}$ reported that low dose desmopressin treatment made significant improvements in health-related QOL compared to placebo in men with nocturia.

In our study, there was no significant difference as regard mean of International Consultation on Incontinence Modular Questionnaire-Nocturia (ICIQ$\mathrm{N}$ ) before treatment but in group A it was significantly decreased after treatment and in both groups it significantly decreased from before to after treatment (12 week) but more in Group A. These results agree with Mohammed and Al-Hakeem ${ }^{(14)}$ who reported that ICIQ-N was significantly improved when desmopressin was add compared to the group that didn't use it.

Collectively, these data support the use of oral desmopressin $(0.2 \mathrm{mg})$ as an add-on treatment to $\alpha$ blockers for the management of men with BPH/LUTS suffering from refractory nocturia.

\section{CONCLUSION}

Addition of desmopressin to $\alpha$-blockers is an active therapy for men with BPH and suffering nocturia and this is preferred than $\alpha$-blockers therapy alone.

Financial support and sponsorship: Nil. Conflict of interest: Nil.

\section{REFERENCES}

1. Taha E, Aboumarzouk M, Shokeir A (2018): Oral desmopressin in nocturia with benign prostatic 
hyperplasia: A systematic review of the literature. Arab Journal of Urology, 16(4): 404-410.

2. Schulman C, Asplund R, Desgrandchamps F et al. (2005): The impact of nocturia on health status and quality of life in patients with lower urinary tract symptoms suggestive of benign prostatic hyperplasia (LUTS/BPH). European Urology Supplements, 4(2), 18.

3. Han J, Jung H, Bakker J et al. (2017): Desmopressin for treating nocturia in men. Cochrane Database of Systematic Reviews, (10): 133-136.

4. Wang J, Lin N, Huang W, Chang H (2011): Low dose oral desmopressin for nocturnal polyuria in patients with benign prostatic hyperplasia: a double-blind, placebo controlled, randomized study. The Journal of urology, 185(1), 219-223.

5. Ahmed F, Maarouf A, Shalaby E et al. (2015): The impact of adding low-dose oral desmopressin therapy to tamsulosin therapy for treatment of nocturia owing to benign prostatic hyperplasia. World Journal of Urology, 33(5): 649-657.

6. Berges R, Höfner K, Gedamke M et al. (2014): Impact of desmopressin on nocturia due to nocturnal polyuria in men with lower urinary tract symptoms suggestive of benign prostatic hyperplasia (LUTS/BPH). World Journal of Urology, 32(5): 1163-1170.

7. Hashim H, Blanker H, Drake J et al. (2019): International Continence Society (ICS) report on the terminology for nocturia and nocturnal lower urinary tract function. Neurourology and Urodynamics, 38(2): 499-508.

8. Oelke M, Weiss P, Mamoulakis C et al. (2014): Effects of tadalafil on nighttime voiding (nocturia) in men with lower urinary tract symptoms suggestive of benign prostatic hyperplasia: a post hoc analysis of pooled data from four randomized, placebo-controlled clinical studies. World Journal of Urology, 32(5), 1127-1132.

9. Schneider T, de la Rosette J, Michel C (2009). Nocturia: a non-specific but important symptom of urological disease. International Journal of Urology, 16(3): 249-256.
10. Sakalis I, Karavitakis M, Bedretdinova D et al. (2017): Medical treatment of nocturia in men with lower urinary tract symptoms: systematic review by the European Association of Urology Guidelines Panel for male lower urinary tract symptoms. European Urology, 72(5): 757-769.

11. Miotla P, Dobruch J, Lipiński M et al. (2017): Diagnostic and therapeutic recommendations for patients with nocturia. Central European Journal of Urology, 70(4), 388.

12. Everaert K, Hervé F, Bosch $R$ et al. (2019): International Continence Society consensus on the diagnosis and treatment of nocturia. Neurourology and Urodynamics, 38(2): 478-498.

13. Suvada K, Plantinga L, Vaughan $P$ et al. (2020): Comorbidities, age, and polypharmacy limit the use by US older adults with nocturia of the only FDA-approved drugs for the symptom. Clinical Therapeutics, 42(12): 259-274.

14. Mohammed H, Al-Hakeem Y (2020): Oral desmopressin as an add-on therapy for men with benign prostate hyperplasia they suffering from persistent nocturia. Medico Legal Update, 20(1): 667-671.

15. Chen L, Huang H, Hung W et al. (2016): Comparison of nocturia response to desmopressin treatment in elderly men with and without nocturnal polyuria in real-life practice. International Journal of Clinical Practice, 70(5): 372-379.

16. Delfanian K, Zawada T (2001): DDAVP-associated hyponatremia. South Dakota Journal of Medicine, 54(7): 255-256.

17. Wang Y, Hu H, Xu K et al. (2015): Prevalence, risk factors, and symptom bother of nocturia: a populationbased survey in China. World Journal of Urology, 33(5): 677-683.

18. Koca O, Keles O, Günes $M$ et al. (2012): Desmopressin in the treatment of nocturia with BPH. Turk J Urol, 38:29-31.

19. Weiss $P$, Zinner $R$, Klein $M$ et al. (2012): Desmopressin orally disintegrating tablet effectively reduces nocturia: results of a randomized, double-blind, placebo-controlled trial. Neurourol Urodyn., 31:441-7. 